\title{
Crowing characteristics of Pelung chickens at different age and body weight
}

\author{
INDRAWATI Y. ASMARA ${ }^{1}$, DANI GARNIDA ${ }^{1}$, RUHYAT PARTASASMITA ${ }^{2, \bullet}$ \\ ${ }^{1}$ Faculty of Animal Husbandry, Universitas Padjajaran. Jl. Raya Bandung-Sumedang Km 21, Jatinangor, Sumedang 45363, West Java, Indonesia \\ ${ }^{2}$ Department of Biology, Faculty of Mathematics and Natural Sciences, Universitas Padjajaran. Jl. Raya Bandung-Sumedang Km 21, Jatinangor, \\ Sumedang 45363, West Java, Indonesia. Tel.: +62- 22-7797712. •email: ruhyat.partasasmita@unpad.ac.id, rp2010rikkyo@gmail.com
}

Manuscript received: 5 July 2020. Revision accepted: 28 August 2020.

\begin{abstract}
Asmara IY, Garnida D, Partasasmita R. 2020. Crowing characteristics of Pelung chickens at different age and body weight. Biodiversitas 21: 4339-4344. Crowing characteristics such as duration, frequency, and intensity are important factors to consider in determining a good Pelung. Age and body weight are among other factors being assumed to affect crowing characteristics. The study was conducted to determine the crowing characteristics of different age and body weight. A survey was carried out in Bandung, Cianjur, and Sukabumi districts, West Java Province, Indonesia in which a total of 98 birds was selected using a purposive technique. The observed parameters were the duration, frequency, and intensity of crowing. The duration was the length of crowing measured by seconds. Frequency is several crowing in a particular time measured by times. Intensity is the magnitude of crowing measured by decibel. The crowing was recorded from 7 AM-2 PM. Data were analyzed using descriptive analysis and Mann-Whitney U Test to compare data differences between research areas. The study found that the crowing duration of Pelung roosters tends to increase in older birds, but the decrease in heavier birds. Crowing frequency increase along with age and body weight. Crowing intensity is similar in different age groups, while the intensity tends to decrease in the heavier group. The results provide evidence that age and body weight of chickens are an important aspect in Pelung contest and age should be considered as a new category in Pelung contest.
\end{abstract}

Keywords: Age, bodyweight, chicken, crowing, Pelung

\section{INTRODUCTION}

Local chickens have multifaceted values, including economic and socio-economic values. This is because local chickens, like other animal genetic resources (AnGRs) in the world, are kept in diverse socio-economic and physical production conditions (Faustin et al. 2010; Gondwe and Wollny 2007). These conditions have formed AnGR breeds based on farmer's preferences (Hannote et al. 2005). Farmer's preferences influence considerably in creating chickens for a particular purpose i.e. for hobby or leisure purposes (Komiyama et al. 2016; Bortoluzzi et al. 2018). In Indonesia, local chickens provide animal protein and have an economic contribution to rural people (Diwyanto \& Iskandar 1999). Furthermore, local chickens are parts of Indonesian history and their roles are important in sociocultural and religious aspects of particular communities (Sidadolog 2007). In addition, some chickens are developed for entertaining purposes due to their unique characteristics such as distinctive vocalization.

Kokok balenggek, Gaga, or Ketawa and Pelung chickens are local Indonesian chickens developed for their unique crowing characteristics (Sulandari et al. 2007; Partasasmita et al. 2017). In particular, a rooster of Pelung chickens can be identified by their long and rhythmic vocalization. The chickens can crow for 11 (Nataamijaya 2005) until 15 seconds (HIPPAPI 2005). The crowing duration can be divided into initial, middle, and end sound (syllable). Gaga chicken can crow for 6.71 to 7.67 seconds
(Zulistiana and Abinawanto 2017), whereas Kokok Balenggek can crow for 2.08 to 4.43 seconds (Rusfidra 2007). In addition to its unique vocalization, Pelung has distinguishing body figure compared to other local chickens. Adult male Pelung chickens can reach 5,400 g in weight, whereas a female adult can reach 4,500 g. The hens can produce 39-68 eggs per year (Sulandari et al. 2007). Pelung has no distinctive pattern or color of plumage. However, red, black, and green plumage is commonly found in male chickens, while black plumage is commonly found in females (Sulandari et al. 2007; Partasasmita et al. 2016). A study carried out by Asmara et al. (2019b) showed that red and black were the primary plumage color for male Pelung chickens. Most of the female Pelung chickens have black and yellow-brown plumage color (Asmara et al. 2019a).

Pelung were initially kept and developed by people in Cianjur District, West Java Province. Decree No. 2918/2011 issued by Minister of Agriculture officially (2011) declared that Pelung is an indigenous chicken breed in Indonesia that needs protection and conservation. It was reported that Pelungs are threatened because of their reduced population sizes (Asmara 2014). However, the presence of Pelung contests may halt Pelung from extinction because the contest promotes Pelung existence; as a result, it would increase Pelung population (Asmara 2014). The contests are perceived as a market place in which hobbyists and farmers would find good breeds (Asmara et al. 2018). Duration, intensity and distinctive 
sound pattern of crowing are indicators for a good Pelung rooster (HIPPAPI 2012). In the contest, a rooster competes to win singing and or performance categories. Duration and sound patterns of crowing are factors to consider in determining contest winners for the singing category, while body weight and color uniformity of external features are important factors to win the performance category.

Bird produces sounds during expiration (Doupe and Kuhl 1999). The sound is influenced by anatomical and physiological factors (Wallschlager 1980). In particular, the scale of birds naturally affects sound production. Louder crowing would be produced by older and heavier birds (Brackenbury 1978). Pelung keepers believe that age, body weight, and health status influence duration and intensity (volume) of crowing (HIPPAPI 2012). An older and healthy rooster would have longer crowing duration, while a heavier rooster would have lower intensity. Studies about singing characteristics of Pelung chickens are limited. A study conducted by Asmara et al. (2020) indicated that age, body weight, and some body-morphometries of Pelung have correlations with crowing characteristics such as duration and intensity. However, the study did not provide specific evidence about age and body weight at which a rooster would have stable crowing characteristics. The current study was conducted to determine the crowing characteristic of Pelung roosters at different age and body weight. The study was carried out to provide empirical evidence about crowing characteristics of Pelung chickens as inputs for increasing its management system including content management.

\section{MATERIALS AND METHODS}

\section{Description of the research area}

The research areas of study were Cianjur, Sukabumi, and Bandung districts, West Java Province, Indonesia (Figure 1). Cianjur and Sukabumi districts are in southwestern Java Island and the two districts are adjacent. Sukabumi District is at an altitude between 0-2,960 m with rainfall of $2,000-4,000 \mathrm{~mm}$ per year. The annual temperature of the district is $18-30^{\circ} \mathrm{C}$ (Sukabumi District Government 2016). Cianjur District is located at an altitude between 7-2,962 $\mathrm{m}$ with an annual rainfall of 2,610 mm. The annual temperature of the Cianjur District is $24.4{ }^{\circ} \mathrm{C}$ (Cianjur District Office of Information Communication and Statistics 2017). Like Sukabumi and Cianjur districts, Bandung District is situated in highland areas. Several mountains are at an altitude of more than $2,000 \mathrm{~m}$. The rainfall in Bandung District is 1,500-4,000 $\mathrm{mm}$ and has a temperature between $12-24^{\circ} \mathrm{C}$ annually (Local Government of Bandung District 2017).

\section{Research methodology}

The object of the study was male Pelung aged more than six months. A total of 98 roosters were involved in the study derived from three study areas (Sukabumi, Cianjur, and Bandung districts). Data were collected using a purposive sampling method due to limited population information in the research locations. The observed parameter was crowing characteristics including duration, frequency, and intensity of crowing. The duration was the time of crowing length which was measured by seconds. In this study, initial, middle, and end duration (syllable) were measured. Frequency is several crowing in a particular time which was measured by times. Intensity is the magnitude of crowing which was measured by decibel.

In general, the birds involved in the study were kept in a semi-intensive system. In semi-intensive, chickens are usually raised and sought for feed-in confined areas. Shelters are provided to keep chickens from bad weather and a place for chickens to sleep at night. In research areas, Pelung chickens are also fed twice a day (morning and afternoon) by supplementary feed i.e. commercial feed and rice brand. Protein sources such as snail and vitamin sources such as papaya, banana, and tomato are occasionally provided. Health protection for chickens through vaccination and or ethnoveterinary medicine are also provided.

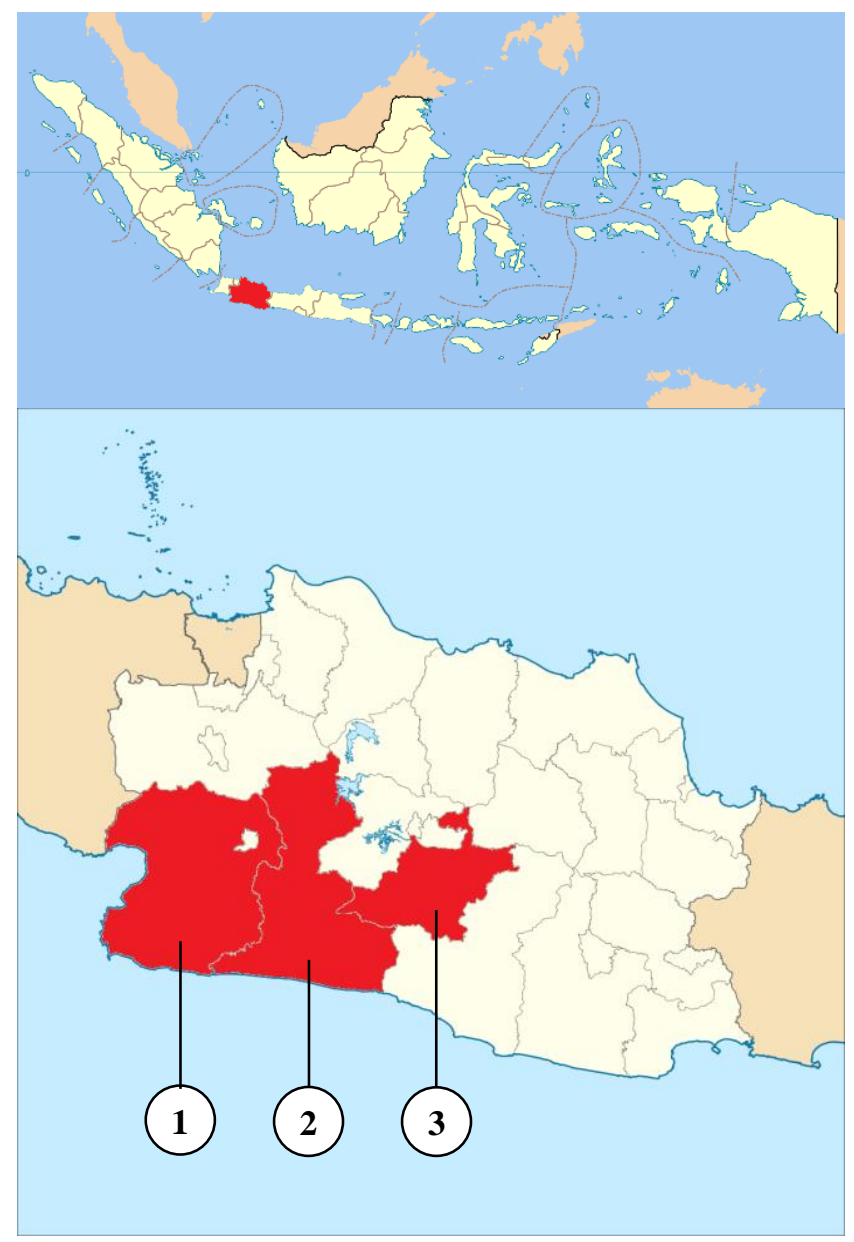

Figure 1. Research areas in: 1. Sukabumi, 2. Cianjur, and 3. Bandung districts, West Java Province, Indonesia 
The selection criterion of samples was age, crowing capacity, and keepers' agreement. Firstly, only mature Pelung roosters aged 6 months or more were selected. Secondly, if birds were categorized as mature, he should have complete crowing. A complete crowing consisted of initial, middle, and end crowing duration (syllable). Thirdly, only birds with keepers' permission involved in the study. To reduce noise and disturbance from humans and other birds, samples were placed individually in 'ajeng', a local name of bamboo cages for rooster Pelung. The cage is commonly placed $80 \mathrm{~cm}$ above the ground. The cage has a dimension of $80 \mathrm{~cm}$ in length, $80 \mathrm{~cm}$ in width, and $100 \mathrm{~cm}$ in height. The crowing sound was recorded using a digital voice recorder in mp3 format from 7 AM-2 PM. The recording process was conducted in a similar environment condition. When it was rain, the recording was canceled. The recorder was located at one side of the cage close to the roosters' head. There were no birds harmed in this study. The birds were placed in a cage by the keepers and the cage was designed to support normal bird behavior. Data were analyzed with Audacity 2.3 to determine the duration, intensity, and frequency of crowing. The Statistical Package for the Social Sciences (SPSS) IBM SPSS statistics 22 was used for data analysis. Descriptive analysis and Mann-Whitney U Test were used in the study. The Mann-Whitney U test is a non-parametric test used to compare differences between two independent groups (MacFarland and Yates 2016).

\section{RESULTS AND DISCUSSION}

\section{Results}

Table 1 shows a descriptive analysis of crowing characteristics between groups of Pelung roosters. The crowing characteristics in the rooster group aged 12 months and less are on average of 8.85 seconds (total duration), 14.09 times (frequency), and 51.12 decibels (intensity). The crowing characteristics in the rooster group aged more than 12 months are on average of 9.00 seconds (total duration), 21.04 times (frequency), and 51.73 decibels (intensity). In terms of bodyweight group, the average number of crowing characteristics in rooster group with bodyweight less than 4 kilograms in 9.35 seconds (total duration), 14.07 times (frequency), and 52.48 decibels (intensity). The average number of crowing characteristics in rooster group with bodyweight more than 4 kilograms is 8.70 seconds (total duration), 16.91 times (frequency) and 50.80 decibels (intensity). The coefficient of variation (CV) for crowing frequency is very high (more than 50\%) in all groups. The high CV value of frequency in each group may indicate less uniformity of data.

Table 1 reveals that duration, frequency, and intensity of crowing tend to be higher in older birds. However, Table 2 indicates that there are no significant differences in crowing characteristics between age groups except for crowing frequency. Roosters aged more than 12 months have higher crowing frequency than those with younger age (12 months and less). Table 1 also reveals that birds with lighter body weight (less than $4 \mathrm{~kg}$ ) tend to have higher crowing duration, while heavier birds have higher frequency and intensity of crowing. Table 2 indicates that lighter roosters have significantly higher middle crowing duration compared to heavier roosters.

\section{Discussion}

Studies about long crowing chickens such as Pelung chickens are limited in Indonesia. In general, knowledge about the crowing characteristic of Pelung chickens is mastered by limited people such as juror of Pelung contest. The knowledge is required to be supported by scientific confirmation. The current study found that the crowing duration of Pelung roosters in all areas tend to increase in older birds. However, the crowing duration between the age group is not significantly different. This finding does not support Asmara et al. (2020) who argued that older Pelung roosters would have longer crowing duration because lung and air sacs are likely to grow at maximum capacity resulting in longer crowing duration in older birds. Interestingly, the current study indicates that in groups with different body weights, heavier birds tend to have a lower duration. Furthermore, the middle crowing duration in heavier chickens is significantly lower than that in lighter bodyweight. This result showed that bodyweight might be a constraint factor for crowing duration. A further study should be conducted to support this evidence.

It is found that total crowing duration both in age and in body weight groups is shorter than that reported by Nataamijaya (2005) who stated that Pelung can crow for 11 seconds. The factors which influence the duration of crowing in Pelung chickens are not clear. The long crowing characteristic seems to be affected by the combination of internal (genetics) and external (nutrition and environment) aspects (Daryono et al. 2020). Some studies showed that genetics is an important element for crowing duration. Different breeds of chickens produced different crowing duration (Kuwayama et al. 1996). In Japanese long crowing chickens, genes control crowing traits (Komiyama et al. 2014). Multiple genes that were inherited by recessive autosomal fashion affect crowing characteristics of Pelung chickens (Daryono et al. 2020). It was assumed that most of male Pelung traded in the markets being impure (Muladno 2008). The decline of crowing duration found in the current study might be caused by the decline of the genetic capacity of Pelung chickens. Hence, a systematic controlled breeding program for Pelung is needed to conserve the breed (Asmara et al. 2020; Asmara 2014). In addition, the management system and health status affect the crowing duration of Pelung chickens (Jarmani and Nataamijaya 1995). As external factor such as nutrition is also assumed to influence the crowing duration of Pelung roosters, studies about feed adequacy and nutrient requirement to sustain the singing capacity of Pelung roosters are required. The decreases in feed quality might be a cause of the decline of Pelung crowing capability (Asmara 2014).

In terms of crowing frequency, breeders and hobbyists of Pelung chickens believe that age is an important factor for crowing frequency. The current study provides evidence that crowing frequency is influenced by age. 
Older roosters would crow more frequently than younger ones. Crowing communicates social hierarchy in groups of roosters (Shimmura et al. 2015) and it is varied with male status (Leonard and Horn 1995). Dominant roosters crow at a higher frequency than that of subordinates (Leonard and Horn 1995) and they crow first followed by its subordinates every morning (Shimmura et al. 2015). Age is among other traits that might influence the formation of status in roosters (Ligon et al. 1990). The current study finding is important for categorizing chickens based on age in a contest. It is commonly found that a winner contest might not crow if it participates in another contest. Status of winner rooster might influence this phenomenon. In Pelung contest, roosters with different ages are placed closely together in a new area. In an unfamiliar place, an individual frequently investigates the new surroundings and other individuals without making noise before interacting aggressively i.e. through fighting (Queiroz and Cromberg 2006). Fighting does not occur in Pelung contest because the rooster is placed in an individual cage. Variation in vocalization including the rate of crowing may predict the future status and consequence of the status of a rooster. A rooster that had more crow in the previous place would have more chance to be dominant in a new arena (Favati et al. 2014). The physical existent or crowing sound of dominant males will inhibit the subordinate males without direct contact (Mench and Ottinger 1991).

Table 1. Description of crowing characteristics of male Pelung chickens

\begin{tabular}{|c|c|c|c|c|c|c|}
\hline \multirow{3}{*}{ Group } & \multicolumn{6}{|c|}{ Crowing characteristics } \\
\hline & \multicolumn{4}{|c|}{ Duration (second) } & \multirow{2}{*}{$\begin{array}{l}\text { Frequency } \\
\text { (times) }\end{array}$} & \multirow{2}{*}{$\begin{array}{l}\text { Intensity } \\
\text { (decibel) }\end{array}$} \\
\hline & Initial & Middle & End & Total & & \\
\hline \multicolumn{7}{|l|}{ Age } \\
\hline \multicolumn{7}{|c|}{$\leq 12$ months $(\mathrm{n}=70)$} \\
\hline Maximum & 1.40 & 9.80 & 4.60 & 12.30 & 36.00 & 62.70 \\
\hline Minimum & 0.80 & 3.00 & 0.60 & 5.20 & 3.00 & 34.00 \\
\hline Mean & $1.07 \pm 0.13$ & $5.65 \pm 1.15$ & $2.12 \pm 0.77$ & $8.85 \pm 1.38$ & $14.09 \pm 8.12$ & $51.12 \pm 4.78$ \\
\hline $\mathrm{CV}(\%)$ & 11.83 & 20.41 & 36.42 & 15.55 & 57.67 & 9.35 \\
\hline \multicolumn{7}{|c|}{$>12$ months $(\mathrm{n}=28)$} \\
\hline Maximum & 1.60 & 8.80 & 4.10 & 12.80 & 67.00 & 60.50 \\
\hline Minimum & 0.80 & 3.50 & 0.50 & 6.30 & 4.00 & 45.20 \\
\hline Mean & $1.13 \pm 0.15$ & $5.81 \pm 1.58$ & $2.05 \pm 0.81$ & $9.00 \pm 1.80$ & $21.04 \pm 15.20$ & $51.73 \pm 3.52$ \\
\hline $\mathrm{CV}(\%)$ & 13.61 & 27.08 & 39.39 & 20.02 & 72.26 & 6.80 \\
\hline \multicolumn{7}{|l|}{ Bodyweight } \\
\hline \multicolumn{7}{|c|}{$<4$ kilograms $(n=29)$} \\
\hline Maximum & 1.60 & 9.80 & 3.60 & 12.50 & 36.00 & 60.50 \\
\hline Minimum & 0.80 & 3.00 & 0.60 & 5.50 & 3.00 & 42.90 \\
\hline Mean & $1.08 \pm 0.14$ & $6.09 \pm 1.48$ & $2.17 \pm 0.72$ & $9.35 \pm 1.54$ & $14.07 \pm 8.43$ & $52.48 \pm 3.69$ \\
\hline $\mathrm{CV}(\%)$ & 13.19 & 24.33 & 32.99 & 16.52 & 59.92 & 7.04 \\
\hline \multicolumn{7}{|c|}{$\geq 4$ kilograms $(n=69)$} \\
\hline Maximum & 1.40 & 8.80 & 4.60 & 12.80 & 67.00 & 62.70 \\
\hline Minimum & 0.80 & 3.10 & 0.50 & 5.20 & 4.00 & 34.00 \\
\hline Mean & $1.09 \pm 0.13$ & $5.53 \pm 1.16$ & $2.08 \pm 0.81$ & $8.70 \pm 1.45$ & $16.91 \pm 11.88$ & $50.80 \pm 4.66$ \\
\hline $\mathrm{CV}(\%)$ & 12.33 & 20.99 & 38.97 & 16.69 & 70.26 & 9.17 \\
\hline
\end{tabular}

Note: $\mathrm{CV}=$ Coefficient of Variation

Table 2. Comparison of crowing characteristics between groups

\begin{tabular}{|c|c|c|c|c|c|c|}
\hline \multirow{3}{*}{ Group } & \multicolumn{6}{|c|}{ Crowing characteristics } \\
\hline & \multicolumn{4}{|c|}{ Duration (second) } & \multirow{2}{*}{$\begin{array}{c}\text { Frequency } \\
\text { (times) }\end{array}$} & \multirow{2}{*}{$\begin{array}{r}\text { Intensity } \\
\text { (decibel) }\end{array}$} \\
\hline & Initial & Middle & End & Total & & \\
\hline \multicolumn{7}{|l|}{ Age } \\
\hline Mann-Whitney U & 754.000 & 966.000 & 932.000 & 962.500 & 715.500 & 969.000 \\
\hline $\mathrm{Z}$ & -1.847 & -0.110 & -0.378 & -0.138 & -2.082 & -0.087 \\
\hline Asymp. Sig. (2-tailed) & 0.65 & 0.912 & 0.705 & 0.890 & $0.037 *$ & 0.931 \\
\hline \multicolumn{7}{|l|}{ Bodyweight } \\
\hline Mann-Whitney U & 895.500 & 740.500 & 904.000 & 764.500 & 882.000 & 771.500 \\
\hline $\mathrm{Z}$ & -0.849 & -2.025 & -0.752 & -1.838 & -0.923 & -1.783 \\
\hline Asymp. Sig. (2-tailed) & 0.396 & $0.04 *$ & 0.452 & 0.66 & 0.356 & 0.75 \\
\hline
\end{tabular}

Note: *p-value is less than the significance level of 0.05 
Testosterone is an underlying factor for crowing and social dominance (Queiroz and Cromberg 2006; Favati et al. 2014). Crowing is also called as testosterone dependent activity (Wada 1986). Testosterone is the most important androgen hormone in birds synthesized and released by the testis and it is responsible for secondary sex features. The hormone facilitates aggressive behavior such as fighting and group establishment. Androgen hormone production increase when the bird is close to puberty (Queiroz and Cromberg 2006). More mature Pelung rooster might have a more stable testosterone hormone mechanism compared to younger rooster. Hence, older birds crow more commonly as it is found in the current study. This finding might indicate that rooster age is an important variable to consider in Pelung contests. Further studies about Pelung behavior in a contest should be conducted in the future.

In the current study, the average crowing intensity both in age and weight group was lower than that documented by the Ministry of Agriculture (2011) who reported that the crowing volume of Pelung roosters is in the range from 60 $\mathrm{dB}$ to $63.89 \mathrm{~dB}$. The crowing intensity in a different age group is relatively similar, while in the weight group, an interesting finding is found. Even though it is not significantly different, the younger roosters tend to have higher crowing intensity. The finding is contrary to Asmara et al. (2020) who reported that the older and bigger birds might have stronger syringeal muscles in regulating crowing intensity. Hence, they would have a higher intensity compared to younger and lighter roosters. The current study provides evidence that body weight is likely to be a constraint to have louder Pelung roosters. However, more studies are required to support this finding.

The current study sheds light on the age and bodyweight of Pelung roosters as crucial aspects in Pelung contest. In particular, the age of a rooster influence crowing frequency; hence, it is important to bring Pelung at a more mature age to avoid the chickens become subordinate and do not make a sound during competition. It is also important to consider age as one of the categories in Pelung contest. More studies about Pelung behavior are required to support this interpretation. Bodyweight is another important factor to consider before keepers taking chickens into contests. Heavier chickens tend to have lower crowing duration. Thus; to keep chickens at a particular bodyweight is important to have higher crowing duration. More samples are needed to determine optimal body weight in which Pelung rooster would produce longer crowing duration.

\section{ACKNOWLEDGEMENTS}

The authors would like to acknowledge Anindya Iswari Suryawan, Delicia Putri Sari, Fianty Antarisa Hartono, Tedi Adam, Muhammad Thoriq Aziz, and Tio Roby Anggara for assisting us during data gathering.

\section{REFERENCES}

Asmara IY. 2014. Risk Status of Selected Indigenous Chicken Breeds in Java, Indonesia: Challenges and Opportunities for Conservation. [Dissertation]. Research Institute for the Environment and Livelihoods, Faculty of Engineering, Health, Science and the Environment, Charles Darwin University, Darwin, NT. [Australia]

Asmara IY, Garnida D, Sulistyati M, Tejaningsih S, Partasasmita R. 2018. Knowledge and perception of Pelung keepers toward chicken contests in West Java, Indonesia. Biodiversitas 19 (6): 2232-2237.

Asmara IY, Garnida D, Tanwiriah W, Partasasmita R. 2019a. Qualitative morphological diversity of female Pelung Chickens in West Java, Indonesia. Biodiversitas 20 (1): 126-133.

Asmara IY, Garnida D, Setiawan I, Partasasmita R. 2019b. Short Communication: Phenotypic diversity of male Pelung chickens in West Java Province, Indonesia. Biodiversitas 20 (8): 2243-2248.

Asmara IY, Garnida D, Partasasmita R. 2020. Short Communication: Duration and volume of the crowing of Pelung chickens of West Java, Indonesia. Biodiversitas 21 (2): 748-752.

Bortoluzzi C, Crooijmans RPMA, Bosse M, Hiemstra SJ, Groenen MAM, Megens HJ. 2018. The effects of recent changes in breeding preferences on maintaining traditional Dutch chicken genomic diversity. Heredity 121: 564-578. DOI: 10.1038/s41437-018-0072-3.

Brackenbury JH. 1978. Respiratory mechanics of sound production in chickens and geese. J exp Bio 72: 229-250.

Cianjur District Office of Information Communication and Statistics. 2017. Geographical location. https: //cianjurkab.go.id/profilcianjur/letak-geografis/

Daryono BS, Mushlih M, Perdamaian ABI. 2020. Vocalization characters and forkhead box P2 (FoxP2) polymorphism in Indonesian crowingtype chicken (Gallus gallus domesticus). Iranian J App Anim Sci 10 (1): 131-140.

Diwyanto K, Iskandar S. 1999. Kampung chickens: A key part of Indonesia's livestock sector in Livestock industries of Indonesia prior to the Asian financial crisis. FAO, Rome.

Doupe AJ, Kuhl PK. 1999. Birdsong and human speech: Common themes and mechanisms. Ann Rev Neurosci 22: 567-631.

Favati A, Leimar O, Radesäter T, Løvlie H. 2014 Social status and personality: Stability in social state can promote consistency of behavioural responses. Proc R Soc B 281: 20132531. DOI: 10.1098/rspb.2013.2531

Faustin V, Adégbidi, Garnett ST, Koudande DO, Agbo V, Zander KK. 2010. Peace, health or fortune? preferences for chicken traits in rural Benin. Ecol Econ 69: 1848-1857.

Gondwe TN, Wollny CBA. 2007. Local chicken production system in Malawi: Household flock structure, dynamics, management and health. Trop Anim Health Prod 39: 103-113.

Hannote O, Toll J, Iniguez L, Rege E. 2005. Farm animal genetic resources: why and what do we need to conserve, paper presented to International Workshop "Options and strategies for the conservation of farm animal genetic resources", Montpellier, France, 7-10 November 2005.

HIPPAPI. 2005. Enchanting of animal genetic resources in Cianjur. HIPPAPI Kabupaten Cianjur, Cianjur, Indonesia. [Indonesian]

HIPPAPI. 2012. Regeneration and training for juries of pelung chickens. HIPPAPI of Cianjur, Cianjur, West Java, Indonesia. [Indonesian]

Komiyama T, Iwama H, Osada N, Nakamura Y, Kobayashi H, Tateno Y, Gojobori T. 2014. Dopamine receptor genes and evolutionary differentiation in the domestication of fighting cocks and longcrowing chickens. PLoS One 9 (7): e101778. DOI: 10.1371/journal.pone.0101778

Komiyama T, Lin M, Ogura A. 2016. A CGH analysis to estimate genetic variations among domesticated chickens. BioMed Res Intl 2016: 1-8. DOI: $10.1155 / 2016 / 1794329$

Kuwayama T, Ogawa H, Munechika I, Kono T, Ichinoe K. 1996. Crowing characteristics of jungle fowls, Japanese native breeds, and white leghorn breed of chicken. J Poultry Sci 33 (2): 89-95.

Jarmani SN, Nataamijaya AG. 1995. Characteristics of the sound of a Pelung chicken. Proceedings of the National Seminar on Animal Husbandry and Veterinary. Center for Animal Husbandry Development. Agricultural Research and Development Agency, Jakarta. [Indonesian]

Leonard ML, Horn AG. 1995. Crowing in relation to status in roosters. Anim Behav 49: 1283-1290. 
Ligon JD, Thornhill R, Zuk M, Johnson K. 1990. Male-male competition, ornamentation, and the role of testosterone in sexual selection in red jungle fowl. Anim Behav 40 (2): 367-373.

MacFarland TW, Yates JM. 2016. Mann-Whitney U Test. In: Introduction to nonparametric statistics for the biological sciences using $\mathrm{R}$. Springer, Cham, Switzerland.

Mench JA, Ottinger MA. 1991. Behavioral and hormonal correlates of social dominance in stable and disrupted groups of male domestic fowl. Horm Behav 25 (1): 112-122.

Minister of Agriculture. 2011. Decree No. 2918/2011: Determination of Pelung chickens as an indigenous breed in Indonesia.

Muladno. 2008. Local chicken genetic resources and production systems in Indonesia. Food and Agriculture Organization of the United Nations, Rome, Italy.

Nataamijaya AG. 2005. Characteristic appearance of feather, skin, foot scales, and beak color of the Pelung chicken in Garut and Sentul chicken in Ciamis. Bul Plasma Nutfah. 11 (1): 1-6. [Indonesian]

Partasasmita R, Hidayat RA, Erawan TS, Iskandar J. 2016. Local knowledge of Karangwangi Village people's, Cianjur District about variation (race), the keeping activity and conservation of chicken (Gallus gallus domesticus Linnaeus, 1758). Pros Sem Nas Masy Biodiv Indon 2 (1): 113-119. [Indonesian]

Partasasmita R, Iskandar J, Rukmana. 2017. Naga people's (Tasikmalaya District West Java, Indonesia) local knowledge of the variations and traditional management farm of village chickens. Biodiversitas 18 : 834-843.

Sidadolog JHP. 2007. Pemanfaatan dan kegunaan ayam lokal Indonesia (Utilisation of local chickens in Indonesia). In: Diwyanto K, Prijono
SN (eds.). Diversity of Indonesian Local Chicken Liver Resources: Benefits and Potential. LIPI Press, Jakarta, Indonesia. [Indonesian].

Queiroz SA, Cromberg VU. 2006. Aggressive behavior in the genus Gallus sp. Braz. J Poultry Sci 8 (1): 1-14.

Rusfidra. 2007. Bioacoustic assessment of the Belengek crown chickens "the local sing fowl" from West Sumatra. National Seminar on Animal Husbandry and Veterinary Technology, Balai Besar Penelitian Veteriner. 21-22 August 2007 [Indonesian]

Shimmura T, Ohashi S, Yoshimura T. 2015. The highest-ranking rooster has priority to announce the break of dawn. Sci Rep 5: 11683. DOI: 10.1038/srep11683

Sukabumi District Government. 2016. Geography of Sukabumi District. https: //sukabumikab.go.id/portal/profil/geografi-kabupatensukabumi. html [Indonesian]

Sulandari S, Zein MSA, Paryanti S, Sartika T, Astuti M, Widjastuti T, Sujana E, Darana S, Setiawan I, Garnida D. 2007. Local chicken genetic resources. In: Diwyanto K, Prijono SN (eds) The Biodiversity of Indonesia's Local Chicken Resources: Benefits and Potential. LIPI Press, Jakarta, Indonesia. [Indonesian]

Wallschlager D. 1980. Correlation of song frequency and body weight in passerine birds. Experientia 36: 412.

Wada M. 1986. Circadian rhythms of testosterone-dependent behaviors, crowing and locomotor activity, in male Japanese quail. J Comparative Physiol A 158 (1): 17-25.

Zulistiana T, Abinawanto A. 2017. Morphometric and bioacoustic analysis gaga chicken (Gallus gallus domesticus) at Bangkalan, Kamal Madura. AIP Conference Proceedings 2023: 020142. DOI: $10.1063 / 1.5064139$ 